\title{
Shear Strength of Crushed Sand Self Compacting Concrete
}

\author{
Dr. B. H. Shinde \\ Asst. Professor, \\ Department of Civil Engineering \\ G. H. Raisoni College of Engineering \& Management \\ Amravati, India.
}

\begin{abstract}
Fine Aggregate is one of the important ingredients of concrete. However dredging of Sand from river beds is hazardous to the environment. This has made the Government to restrictions on the use of river sand in construction. Such cases leads use of crushed sand as an alternative to river sand, due to angular shape and rough texture it gives better bond strength. Compaction of normal concrete is impossible at the place of dense reinforcement where needle vibrator can not reach, at that place Self Compacting Concrete is effective to reach at every corner of formwork, and get compact by its self weight. In design of structures, shear strength of concrete is very important for calculating the quantity of shear reinforcement. Shear strength of concrete depends upon Compressive strength. In this present work an attempt is made to study the shear strength of River Sand Self Compacting Concrete with varying the percentage of shear reinforcement by $0 \%, 0.25 \%$ and 0.50 $\%$ at shear plane of Push-off specimen. Load-deflections variations of SCC with River sand and SCC with Crushed sand are also studied. For compressive and shear test of $100 \mathrm{~mm}$ $\times 100 \mathrm{~mm}$ cube and $150 \mathrm{~mm} \times 150 \mathrm{~mm} \times 450 \mathrm{~mm}$ push-off specimen were used. In this experimental study it is observed that the shear strength of CSSCC becomes more than RSSCC at same w/c ratio.
\end{abstract}

Keywords-Self-Compacting Concrete, Crushed sand, River sand, Fly ash, Shear strength, Compressive strength, Shear reinforcement etc.

\section{INTRODUCTION}

Self compacting concrete (SCC) was first developed in 1988 , to achive durable concrete structures. The creation of durable concrete structures requires adequate compaction by skilled workers. However the gradual reduction in the number of skilled workers in Japan construction industries has led to reduction in the quality of construction work. The necessity of SCC was praposed by Okamura in 1986. Studies to develope SCC including a fundamental study on the warkability of concrete have been carried out by Ozawa in 1989.

Currently India has taken a major initiatives on developing the infrastructure such as express highways, power project and industrial structures etc. to meet the requirements of globalization, in the construction of buildings and other structures concrete plays the rightfull role, but use of large quantity of concrete, has become highly expensive and scarce. In the backdrop of such a fleak atmosphear, there is large demand for alternative materials from industrial waste. In concrete sand is a non-excludable material, but natural sand is expensive due to the excessive cost of transportation from natural resources. Also government restrict to draw sand from river by considering enviornmental problems. As, these constraints make the availability and use of river sand less

\author{
Dr. K. N. Kadam \\ Asso. Professor, \\ Department of Civil Engineering \\ Government College of Engineering, Nagpur, India
}

attractive, a substitute or alternative product to river sand need to be found out.

In such a situation the Crushed sand can be an economic alternative to the river sand. Crushed sand can be defined as residue tailing or other non-valuable waste material after the extraction and processing of rocks to form coarse particle greather than $4.75 \mathrm{~mm}$. The particle shape of crushed sand is more angular with a rougher surface texture, that why it can be gives bettor bonding, so strength of concrete get increases than that of natural sand. problems of durability of concrete and non availibility of river sand,one solution on that problems is Self Compacting Concrete with crushed sand.

\section{EXPERIMENTAL PROGRAM}

SCC mixes with w/c of $0.35,0.41$ and 0.47 using river sand and crushed sand. Fly ash content of $25 \%, 29 \%$ and 33 $\%$ was consider for RSSCC and CSSCC with w/c 0.35, 0.41 and 0.47 respectively. For each mix cubes of $100 \times 100$ $\times 100 \mathrm{~mm}$ and shear specimen of $150 \times 150 \times 150 \mathrm{~mm}$ were cast. Percentage of shear reinforcement was $0 \%, 0.25 \%$ and $0.50 \%$ for each mix

\section{MATERIALS}

\subsection{Cement}

The cement used in this experimental work is " 53 grade Ordinary Portland Cement". Properties of cement are tested as per IS 12269 - 1987 [33]. Test results are presented in Table 1 .

\subsection{Aggregates}

Natural sand from Wardha river and Crushed sand from locally available Vertical Shaft input (VSI) crusher is used. Various tests such as specific gravity, water absorption, moisture content, sieve analysis etc. have been conducted as per IS 2386. The test results are presented in Table (2) and (3). Crushed well graded aggregate black trap basalt of size $10 \mathrm{~mm}$ was used, and confirming the requirement of IS 383-1970 as coarse aggregate.

\subsection{Water}

SCC.

Potable laboratory tab water was used for mixing of

\subsection{Super Plasticizer}

Poly-carboxylate ether based Super plasticizer Sika ViscoCrete 10R, Brownish color is used as high range water reducing admixture in the experimental work. They satisfy the requirement of IS 9103-1999 (Amended 2003). 
Table 1: Properties of Cement

\begin{tabular}{|c|c|}
\hline Properties & Results \\
\hline Fineness & $2.9 \%$ \\
\hline Specific Gravity & 3.15 \\
\hline Standard Consistency & $30 \%$ \\
\hline $\begin{array}{ll} & \text { Setting Time } \\
\text { a) } & \text { Initial } \\
\text { b) } & \text { Final }\end{array}$ & $\begin{array}{l}110(\mathrm{~min}) \\
248(\mathrm{~min})\end{array}$ \\
\hline Soundness & $3.0(\mathrm{~mm})$ \\
\hline
\end{tabular}

Table 2: Physical Properties of Aggregates

\begin{tabular}{|c|c|c|c|}
\hline \multirow{2}{*}{ Properties } & \multicolumn{3}{|c|}{ Results } \\
\cline { 2 - 4 } & $\begin{array}{c}\text { F. A. } \\
\text { (River) }\end{array}$ & $\begin{array}{c}\text { F. A. } \\
\text { (Crushed) }\end{array}$ & C. A. \\
\hline Particle Shape & Rounded & Cubical & Angular \\
\hline Particle Size (mm) & 4.75 & 4.75 & 10 \\
\hline Fineness Modulus & 2.683 & 2.873 & 6.0 \\
\hline Specific Gravity & 2.63 & 2.88 & 2.6 \\
\hline Silt /Dust Content & $3.3 \%$ & $8.6 \%$ & Nil \\
\hline Surface Moisture & Nil & Nil & Nil \\
\hline Water absorption & $1.43 \%$ & $1.94 \%$ & $2.84 \%$ \\
\hline Bulk Density & $1723 \mathrm{~kg} / \mathrm{m}^{3}$ & $1810 \mathrm{~kg} / \mathrm{m}^{3}$ & $\begin{array}{c}1620 \\
\mathrm{~kg} / \mathrm{m}^{3}\end{array}$ \\
\hline
\end{tabular}

Table 3: Sieve Analysis of Aggregates

\begin{tabular}{|c|c|c|c|}
\hline \multirow{2}{*}{ Sieve Size } & \multicolumn{3}{|c|}{ \% Passing } \\
\cline { 2 - 4 } & $\begin{array}{c}\text { F.A. } \\
\text { (River) }\end{array}$ & F.A. (Crushed) & C. A. \\
\hline $10 \mathrm{~mm}$ & 100 & 100 & 100 \\
\hline $4.75 \mathrm{~mm}$ & 100 & 100 & 0.00 \\
\hline $2.36 \mathrm{~mm}$ & 96.3 & 92.2 & -- \\
\hline $1.18 \mathrm{~mm}$ & 70.7 & 59.2 & -- \\
\hline $600 \mu$ & 46.6 & 35.7 & -- \\
\hline $300 \mu$ & 14.9 & 17.0 & -- \\
\hline $150 \mu$ & 3.2 & 8.6 & -- \\
\hline F. M. & 2.683 & 2.876 & 6.03 \\
\hline
\end{tabular}

\subsection{Viscosity Modifying Agent}

Biopolymer based Viscosity Modifying Agent Sika ViscoCrete 4R, Brownish color is used as viscosity modifying admixture in the experimental work.

\subsection{Fly ash}

Fly Ash of Sifiya thermal power plant Amravati is used in concrete in dry powder form. Color of Fly ash is light gray.

\section{MIX PROPORTIONS OF SCC}

The mix proportions was same for River Sand Self Compacting Concrete (RSSCC) and Crushed Sand Self Compacting Concrete (CSSCC), only Dosage of Admixture and VMA was changed according to workability of concretes for satisfy the Fresh properties of SCC as per EFNARC Specifications. Proportions of ingredients are given in Table 4.

Table 4: Quantities per 1 cum of RSSCC and CSSCC

\begin{tabular}{|c|c|c|c|}
\hline \multirow{2}{*}{ Materials } & \multicolumn{3}{|c|}{ Proportion by weight $\left(\mathbf{k g} / \mathbf{m}^{\mathbf{3}}\right)$} \\
\cline { 2 - 4 } & Mix-1 & Mix-2 & Mix-3 \\
\hline Cement & 400 & 450 & 500 \\
\hline Fly Ash & 132 & 130 & 120 \\
\hline F. A. & 885 & 792 & 800 \\
\hline C. A. & 81 & 742 & 800 \\
\hline Water & 188 & 185 & 175 \\
\hline
\end{tabular}
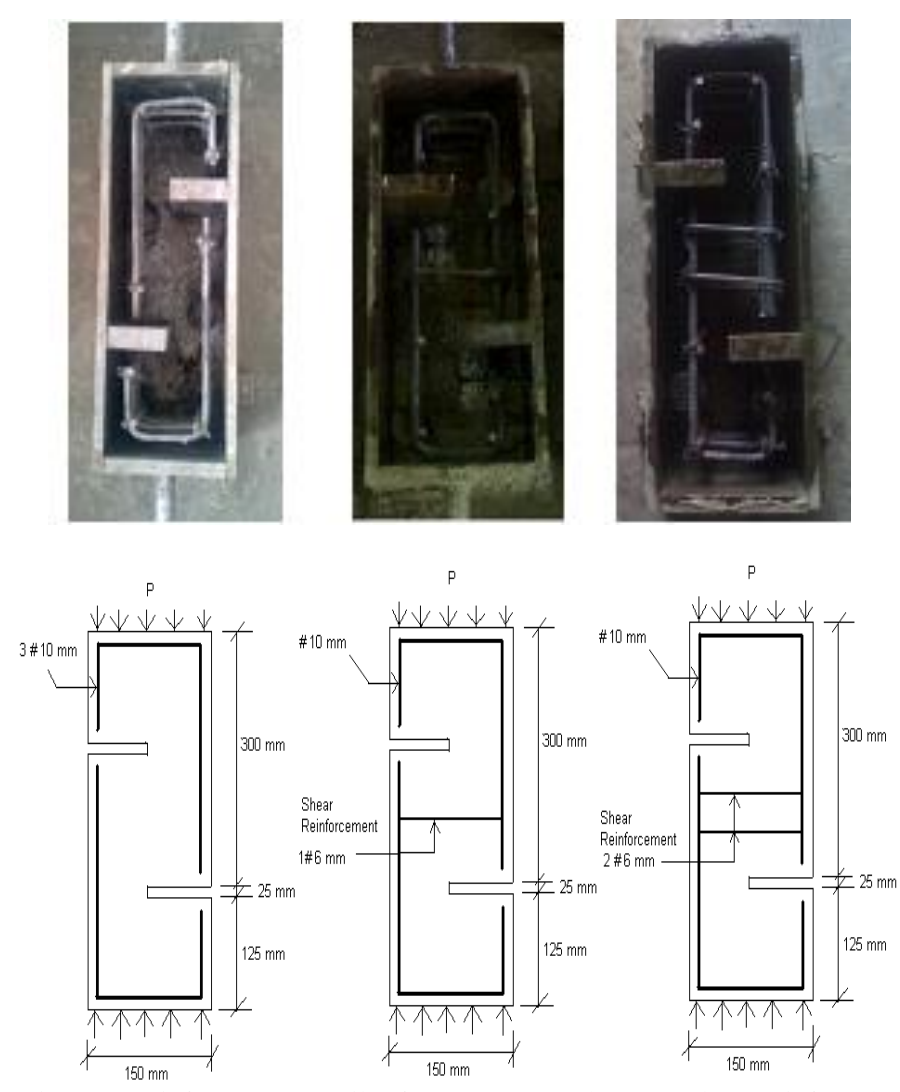

Figure 1: Reinforcement Details of $0 \%, 0.25 \%$ and $0.50 \%$ Shear Reinforced Push-off Specimens

\section{TEST PROCEDURE}

Compressive test was carried out as per I.S. 5161975. For compression test total 18 specimens of size $100 \mathrm{x}$ $100 \times 100 \mathrm{~mm}$ cube were used. For compressive test, compression testing machine of capacity $3000 \mathrm{kN}$ were used. And rate of loading was kept $1.5 \mathrm{kN} / \mathrm{sec}$. For Shear test total 54 numbers of push-off specimens were cast. After 28 days water curing test were performed using Universal Testing Machine (UTM) of capacity 40 tons, and for measuring deflection, use dial gauge of capacity $20 \mathrm{~mm}$ of least count $0.01 \mathrm{~mm}$.

\section{TEST RESULTS}

Compressive and Shear strength of River Sand Self Compacting Concrete (RSSCC) and Crushed Sand Self Compacting Concrete (CSSCC) for w/c ratio 0.47, 0.41 and 0.35 are given in Table- 5 and variation of shear strength with respect to Compressive strength of RSSCC and CSSCC are shown in figure-2.

Table 5: Compressive and Shear strength of RSSCC and CSSCC

\begin{tabular}{|c|c|c|c|c|c|}
\hline \multirow{2}{*}{ W/C } & \multirow{2}{*}{$\begin{array}{c}\text { Types } \\
\text { of SCC }\end{array}$} & \multirow{2}{*}{\begin{tabular}{c} 
Comp. \\
Strength \\
\cline { 4 - 6 }
\end{tabular}} & & \multicolumn{3}{|c|}{ Shear Strength (MPa) } \\
\cline { 4 - 6 } & & Sr- 0 \% & Sr- 0.25 \% & Sr- 0.50 \% \\
\hline \multirow{2}{*}{0.47} & RSSCC & 38.33 & 5.755 & 6.453 & 8.197 \\
\cline { 2 - 6 } & CSSCC & 40.00 & 6.278 & 7.150 & 9.592 \\
\hline \multirow{2}{*}{0.41} & RSSCC & 47.00 & 6.627 & 7.674 & 9.069 \\
\cline { 2 - 6 } & CSSCC & 51.00 & 7.325 & 8.371 & 9.766 \\
\hline \multirow{2}{*}{0.35} & RSSCC & 55.00 & 7.325 & 8.720 & 9.941 \\
\cline { 2 - 6 } & CSSCC & 62.67 & 7.848 & 9.418 & 10.464 \\
\hline
\end{tabular}

$\mathrm{Sr}=$ Percentage of Shear Reinforcement 


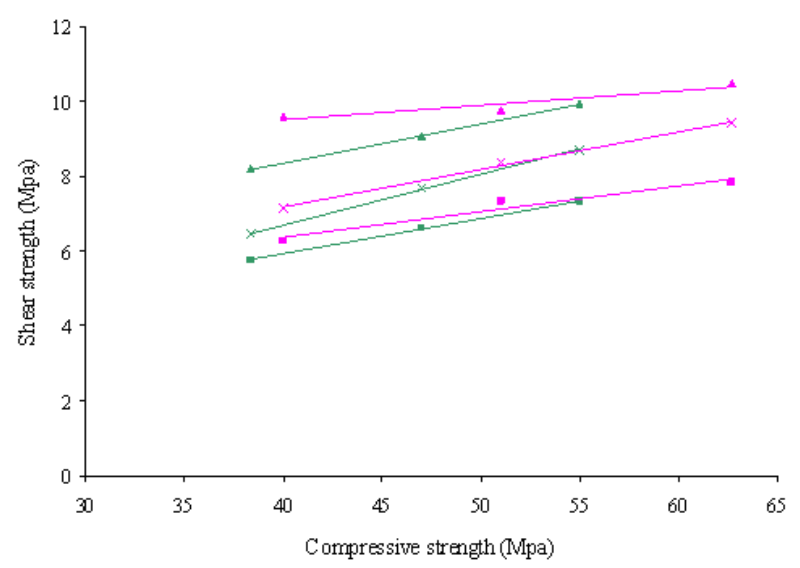

Figure 2: Variation of Shear Strength with Respect to Compressive Strength

\section{LOAD VERSES DEFLECTION}

Deflection was measure at the time of testing at interval of $400 \mathrm{~kg}$, and Load verses Deflections of $0 \%, 0.25 \%$ and $0.50 \%$ shear reinforced specimens of RSSCC and CSSCC at w/c $0.47,0.41$ and 0.35 was measured.

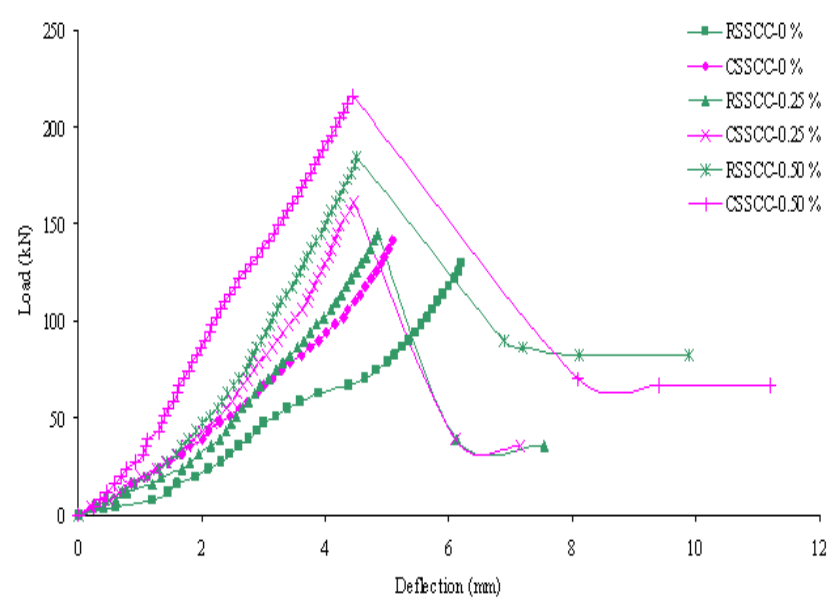

Figure 3: Variation Load-Deflection of Push-off Specimen with w/c 0.47.

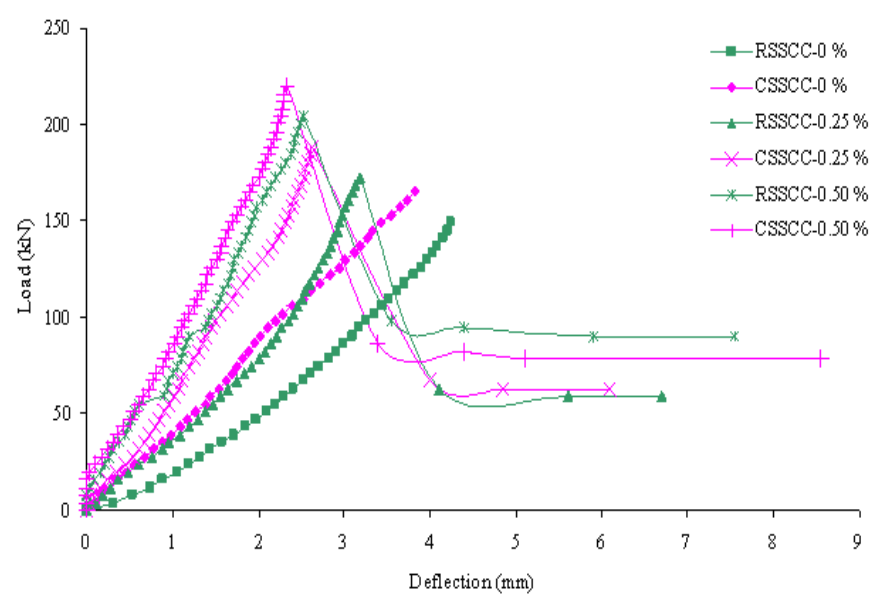

Figure 4: Variation Load-Deflection of Push-off Specimen with w/c 0.41

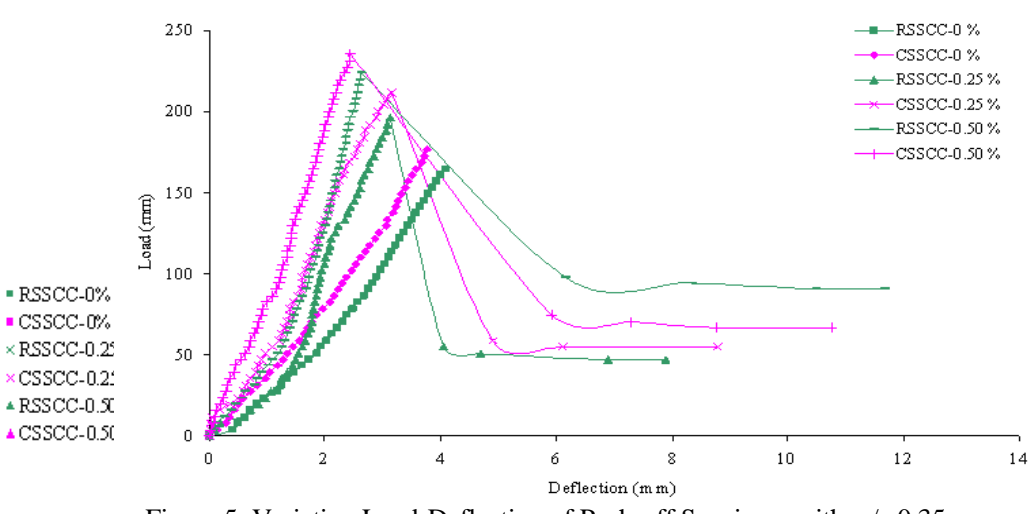

Figure 5: Variation Load-Deflection of Push-off Specimen with w/c 0.35

\section{RESULTS AND DISCUSSION}

The shear strength of CSSCC occurs more than RSSCC at same w/c ratio and percentage of shear reinforcement. Rough surface of crushed sand gives bettor interlocking with other materials in concrete, that's why RSSCC gives more strength than that of RSSCC. The figure (2) shows that the difference between shear strength of CSSCC and RSSCC get decreases when increase the compressive strength of concrete. In shear the failure of $0 \%$ shear reinforced push-off specimen is sudden failure but the failure of $0.25 \%$ and $0.50 \%$ shear reinforced push-off specimen is ductile manner, after failure the load get decreases up to certain limit and after that it remain constant but deflection continuously get increase. Load carrying capacity get increase when increasing the percentage of shear reinforcement at shear plain. The shear reinforcement is across the shear plane that's why it contributes to resist the load, (increase the load resisting area) and load carrying capacity get increase.

Figure (7), (8) and (9) show that the deflections occurs in $0 \%$ shear reinforced push-off specimen is more at minimum load, but in $0.25 \%$ and $0.50 \%$ shear reinforced push-off specimen deflection occur is less at same loading. The rate of gaining shear load at minimum deflection is get increases when percentage of shear reinforcement gets increase. Deflections get decreases at same loading when increasing the percentage of shear reinforcement. The area under the curve goes increases when increasing the percentage of shear reinforcement. The area under the curve of $0.50 \%$ shear reinforced push-off specimen is more than that of $0 \%$ and $0.25 \%$ shear reinforced push-off specimen at same w/c. The area under the curve represents the durability of that concrete. Furthermore the area under the curve is large; the durability of that concrete is high. Shear strength of RSSCC and CSSCC at $0.25 \%$ and $0.50 \%$ shear reinforcement, observed to be increased by $12.121 \%, 42.424 \%$ and 13.889 $\%, 52.78 \%$ than that of $0 \%$ shear reinforcement at w/c 0.47 . Shear strength of RSSCC and CSSCC at shear reinforcement $0.25 \%$ and $0.50 \%$ observed to be increased by $15.790 \%$, $36.842 \%$ and $16.667 \%, 33.324 \%$ than $0 \%$ shear reinforcement at w/c 0.41 respectively. Shear strength of RSSCC and CSSCC at shear reinforcement $0.25 \%$ and 0.50 $\%$ observed to be increased by $19.048 \%, 35.714 \%$ and by 20 $\%, 33.333 \%$ than that of $0 \%$ shear reinforcement at w/c 0.35 . The shear strength increases in CSSCC at $0 \%$ shear reinforcement by $9.088 \%, 10.533 \%, 7.140 \%$ at w/c at W/C 
$0.47,0.41$ and 0.35 respectively. In same above W/C but $\%$ age of Shear reinforcement is $0.25 \%$, the Shear strength increases in CSSCC by $10.801 \%, 9.083 \%$ and $8.005 \%$. Shear strength increases of CSSCC at $0.50 \%$ Shear reinforcement by $17.018 \%, 7.686 \%$, and $5.261 \%$ at W/C $0.47,0.41$, and 0.35 respectively

\section{CONCLUSION}

The Crushed sand Self compacting concrete gives more shear strength than that of River sand Self compacting concrete at same w/c ratio and percentage of shear reinforcement.

The Crushed sand self compacting concrete gives more load at minimum deflection than that of River sand self compacting concrete. The rate of increment of load carrying capacity of CSSCC is more than RSSCC. RSSCC.

Area under the curve is more in CSSCC than that of

\section{REFERENCES}

[1] Hajime Okamura and Masahiro Ouchi, "Self Compacting Concrete" journal of Advanced Concrete Technology, Vol. 1, No. 1, April 2003, pp. 5-15.

[2] Malathy, T. Govindasamy, "Development of Mix Design Chart for Various Grades of Self Compacting Concrete" ICI Journal, OctoberDecember 2006, pp. 19-28.

[3] Erhan Guneyisi," Fresh Properties of Self Compacting rubberized Concrete Incorporating with Fly Ash", journal of Materials and Structures, October 2009.

[4] K. M. A. Hossain, M.ASCE; and M. Lachemi, "Bond behavior of Self-Consolidating Concrete with Mineral and Chemical Admixtures", ASCE, Vol. 20, No. 9, September 2008, pp. 608-616.

[5] M.R. Chitlange, Dr. P.S. Pajgade, Dr. P.B. Nagarnaik, "Experimental Study of Artificial Sand Concrete", Journal of IEEE, June 2009, pp.1050-1054.

[6] R. Ilangovana, N. Mahendrana, and Nagamanib, “ Strength and Durability Properties of Concrete Containing Quarry Rock Dust as Fine cAggregate", ARPN Journal of Engineer and Applied Sciences, Vol.3, No. 5, October 2008, pp. 20-26.

[7] M. Shahul Hameed, A. S. S. Sekar, "Properties of Green Concrete Containing Quarry Rock Dust and Marble Sludge Powder as Fine Aggregate", ARPN Journal of Engineer and Applied Sciences, Vol. 4, No. 4, June 2009, pp. 83-89.

[8] T. Horiguchi, N Saeki, Y. Fu.jita, "Evaluation of Pullout test for Estimating Shear, Flexural. And Compressive strength of fiber reinforced Silica Fume Concrete", ACI Materials Journal Vol. 85. No. 2, March-April 1988, pp. 126-131.

[9] Helen Dulacska, "Dowel Action of Reinforcement Crossing Cracks in Concrete", ACI Journal, Vol. 69, December 1972, pp. 754-756.

[10] Nicolas Saenz, Chris P. Pantelides, Lawrence D. Reaveley, "Strutand-Tie Model for Shear-Reinforced Polymer Composites", ACI Structural Journal, Vol.101, No. 6, Nov.-Dec. 2004, pp. 863-871.

[11] M. A. Mansur, T. Vinayagam, Kiang-Hwee Tan, "Shear Transfer across a Crack in reinforced High-Strength Concrete", ASCE, Vol. 20, No. 4, April 2008, pp. 294-302.

[12] Amir A. Mirsayah, Nemkumar Banthia, "Shear Strength of Steel Fiber-Reinforced Concrete", ACI Materials Journal Vol.99, No. 5, Sept.-Oct. 2002, pp. 473-479

[13] Mariano Valle, Oral buyukozturk, "Behavior of Fiber Reinforced high-Strength Concrete under Direct Shear", ACI Materials Journal Vol. 90, No. 2, March-Apr 1993, pp. 122-133.

[14] Bryan Barragan, Ravindra Gettu, Luis Agullo, Raul Zerbino, " Shear Failure of Steel Fiber-Reinforced Concrewte Based on Push-off Tests", ACI Materials Journal Vol. 103, No. 4, July-August 2006, pp. 251-258. 